\title{
The Impact of Information and Communication Technology (ICT) on Educational Improvement
}

\author{
Mohammad Reza Ghaznavi (corresponding author) \\ Master of education technology, Sistan and Baluchestan, Iran
}

Alemeh Keikha

Master of education management, University of Zabol, Iran

Nour-Mohammad Yaghoubi

University of Sistan and Baluchestan, School of management and accounting, Department of Management, Zahedan, Iran, P.O.Box: 98135/987

Received: December 20, 2010 Accepted: February 10, 2011 doi:10.5539/ies.v4n2p116

\begin{abstract}
Information and communication technology has become an inseparable part of human life and caused doing things more through the consumption of less time and cost. The present research aims to study the effect of information and communication technology on the educational improvement of third grade high school students in Khash-Iran . The research was a descriptive survey. The population included the third grade high school students of Khash city who were about 1900 people studying in 35 educational units in 2010. The sample size was determined using Kirgizia and Morgan statistical tables and was determined to be 320 people. Random multistep method was employed for sampling among male and female students in proportion with the community size. A researcher-made 24-quenstion questionnaire with a grading scale of Likret type was used for data collection whose validity and reliability was confirmed by Cronbach's $\alpha$. The method of measurement type was used for data analysis; frequency distribution table, frequency percentage and diagram drafting were used descriptive statistics section, The Khi (chi-square), U Mann -Whitney and Kruskal-Wallis statistical tests were used in inferential statistics section with regard to the measurement scale. SPSS was used to analyze data. Research findings reveal that using information and communication technology is effective in increasing educational motivation, improving questioning skill, improving research spirit and raising school marks. It is generally effective on third grade high school students' educational improvement to a great extent. This effect was the same among male and female students with different average scores, ages and fields. However, its effect on vocational and high schools students was different.
\end{abstract}

Keywords: Information and communication technology, Educational improvement, Internet, Effectiveness

\section{Introduction}

$21^{\text {st }}$ century is knowledge and information revolution century. It means the conversion of industrial society into informational society; and today the richest countries and human societies are those who have access to the greatest knowledge, awareness and information. Certainly, the leadership of future education will be assumed by ICT. (Norouzi et al., 1387: 10). Technology will have a critical role in $21^{\text {st }}$ century (Alinston, 2002: 317) . Therefore, nowadays using IT is essential for every organization (Kurupparachchi et al., 2002: 126). During the last semi-century, modern organizations have increased investing on IT, because they believe that IT has a positive effect on the organizational performance (Muata et al., 2003: 1). In the organizations, data network has become as important as the social network and they are actually has been merged together (Baines, 1998: 49). Finally it must be noted that nowadays IT application is a common characteristic of organizations and has been proved as a vital factor in the success of many organizations (McClea \&Yen, 2005: 8).

By introducing information and communication technology in teaching and curricular program domains, classroom management was generally revolved and it is performed by a research-based and student-based procedure. The responsibility of the teachers is no longer gathering and transferring information, but he/she assumes various responsibilities and he/she should be a multi-skilled person. Closed, limited and concentrated pattern of teaching resources and traditional learning is also converted into open, non-concentrated, and unlimited pattern and devoid of 
time and space limitations and presents very procedural results for teaching and learning system. Curricular subjects obtained from technology have multi-dimensional and motional nature and its designers have process-based policy not context-based one. In traditional attitude towards this subject, teacher- based policy is the basis and foundation of human teaching. But in new attitude, the basis of teaching and training has been established student-based (Mohammadi, 1381: 2).

It is undeniable that the unilateral form material-based systems are being destroyed and educational methods have been established based on exploiting from bilateral values of learning according to new communicative systems and video-audio framework. Ineffectiveness of traditional methods of teaching in the present age is an accepted issue and the application of information and computer technologies in order for quantitative and qualitative improvement of teaching process is inevitable (Yazdchi, 1385: 4).

Educational improvement is one of the important educational essentials and naturally, it should be revolved proportional to information age. By reviewing the existing statistics and information about the development of ICT in developing countries' education, we find out that in many countries such as the developed and developing countries, to equip the schools with various facilities such as computer and Internet, comprehensive programs have been compiled and it is a long time when they have paid a special attention to the role of information technology tools in their curricular programs and have spent a considerable cost to implement proper tools in teaching. The invention of new educational methods, exploiting from computer in classrooms, exploiting from educational software and multi-media, exploiting from Internet, e-mail and ... are of new consequences of implementing information and communication technology (Zoghipour \& Ghaffari, 1384: 14).

Studies show that exploiting from modern technologies like computer and world web in classrooms, gives this possibility to the students to learn by faster speed and better performance (Mehmet, 2004) and have more satisfaction by attending in the classroom (Milleken \& Bames, 2002).

Today, students are born in audio, video and motional world. Therefore, teachers' attempts for their training by exploiting from educational media and methods during past period will be useless or will not be followed by a significant result. Therefore, it is necessary for the teachers both know well about new educational media and technology and also contact with it by a positive attitude (Tileston, 2004).

Regarding the importance of educational improvement in teaching and training process and the necessity of quality enhancement in teaching and much better exploiting from ICT phenomenon, making some facilities to implement these innovations in teaching and learning process is very vital. Therefore, the study of phenomena effects of application information and communication technologies in different fields is important. Scientists generally and students specifically are of main consumers of these technologies. Internet devotes an important part of educational and leisure time activities of students to itself and there is this possibility that exploiting from this phenomenon may have effect on their educational improvement. Hence, the study of outcomes of using new technologies is eligible to be studied in terms of the recognition of consequences and effects that may have on students (Journal of the Faculty of Literature and Humanities, 15(58): 35).

GhasemiNejad (1384) conducted a research as Determination of practical procedures for computer workshops activization of high schools in Isfahan province, and achieved these results = workshop activization is dependent on educational, administrative, structural, official, motivational and recreational measurements. In respect of educational procedures, the most important measurement in terms of teachers and instructors is including a curricular course in students, curricular program. Presenting students, curricular homework using of information and communication technology was another recommendation.

Montazeri and Vakili and seyyed Ebrahimi (1385) in a research called as the effect of teaching revolutions of information technology in Education in Tehran's Hakimzadeh high school, achieved these results that implementing information technology in Education not only has become acceleration and facilitation factor and also educational quality enhancement factor, but also it has become a factor of changes in the concepts of traditional teaching essentials. Therefore, the amount of importance and relying on textbook and curricular materials in each class, evaluation approach of teaching methods, learning value, the approach of relationship between teacher and student, all are of cases which have been changed by exploiting from information technology.

Zamani and Isfahani (1386) conducted a research called as the amount of instructors achievement and their exploiting from ICT in secondary schools in Isfahan and achieved this result that instructors, access amount to hardware possibilities (facilities) at home and in the school is in a desired extent. However, access amount in software field is not so desired. Also, the application of ICT in three domains of teaching, research and communication is less than the desired level. 
Islami (1387) in a research titled as the study of development fields of ICT in general teaching schools in Mazandaran province, achieved these results that computer possibilities and equipments in our schools are placed in a low position and teachers, LCDL skill position is not in a desired level and teachers enjoy high interest and motivation to use information and communication technology in teaching and instruction and the position of the existing educational contents has been evaluated as good.

Sandholtez \& Dwyer (1994) in a research as a look at attending students in the classroom empowered by technology, pointed out the issue of increase in the motivation and interest of teachers and students in using of technology for learning and have presented (posed) the following points = students , high interest in working with computer caused their learning shall be performed by faster speed. This interest has also increased teachers motivation for technology integration in teaching - learning process. Students devote more time to perform homework and research projects using of the computer and they are even busy by working with computer during their free time.

Pelegram Velva (2003) based on experiences obtained from SITES II (second Information Technology in Education study) program expresses that it seems ICT has valued to support learning environments where they are increasingly student-based. Teachers have reported that students have high motivation and discipline problems have been solved. Also, according to teachers saying, despite of becoming work volume heavier (which is the result of learning introductions preparation), teachers are much more comfortable in class environment and enjoy this that they have been able to teach their students better. In addition, they have reported that their cooperation with other teachers has been improved and this has been caused an increase in their motivation.

Regarding to the mentioned issues, this research by a goal to study the effect of ICT on the educational improvement of third grade high school students in khash province was performed. In addition, the existence of meaningful difference between the effect of information and communication technology on the educational improvement of third grade high school students has been reviewed based on the variables of gender, kind of academy, age, educational field and the average. In order to achieve the mentioned goals, during research performance, the following hypotheses have been tested:

General hypothesis: using of information and communication technology has an impact on the educational improvement of third grade high school students.

1. Using of information and communication technology has an impact on increase in educational motivation of third grade high school students.

2. Using of information and communication technology has an impact on increase in question-making skill of third grade high school students.

3. Using of information and communication technology has an impact on increase in research spirit of third grade high school students.

4. Using of information and communication technology has an impact on increase in curricular scores of third grade high school students.

\section{Research Methodology}

Regarding to the mentioned goal and hypotheses in this study, research approach is descriptive one of survey kind.

Statistical population in this research has been all third grade secondary school students in high schools and art academies in khash province by a population of 1900 persons who are studying in 35 academic units during academic year 1388-1389, which out of them, 320 persons were selected by kerjisi and Morgan table as samples (Table 1-1 and table 1-2).

In this study, two library (using library books, theses, journals, Quarterly and valid and related to research (research-related) electronic journals) and field methods by a questionnaire containing 24 questions realized by likert spectrum which had been compiled proportional with the hypotheses, are used for data collection. Its content reliability in terms of guidance professors and counselors and a number of educational science group professors, view was confirmed. And Cronbach's $\alpha$ for this scale was 0.86 .

In order for research data analysis, two statistical methods of descriptive and deductive kinds were used. In descriptive analysis, statistical characteristics such as frequency, frequency percentage and diagram drawing were used. In deductive analysis, for data analysis by nominal scale, chi-square test was used (Delavar, 1379: 221), and in relation to data by relative scale regarding to independent groups (two groups and multi groups), u Mann Whitney and kruskal-wallis tests have been used (Hassanzadeh, 1387: 284).

\section{Research Findings}

First hypothesis of research: using of information and communication technology has an impact on increase in educational motivation of third grade secondary school students (Table 2-1 and table 2-2). 
Regarding to the data of table (2-1), 0 percent have answered to very low and low options, 5.3 percent have answered to "To some extent" options, 70.6 percent have answered to high option and 24.1 percent have answered to very high option. The most frequency is related to high option.

Regarding to table (2-2), the calculated chi-square (12.171) is larger than the value of chi-square in the table (9.21), therefore, by a 99 percent confidence, it can be said that there is a meaningful difference between the observed frequencies and the expected frequencies. And this result indicates that using of information and communication technology has an impact to a high extent on increase in educational motivation of third grade secondary school students.

Second hypothesis of the research: using of information and communication technology has an impact on increase in question-making skill of third grade secondary school students (Table 3-1 and table 3-2).

Regarding to the data of table (3-1), 0 percent have answered to very low and low options , 2.2 percent have answered to. To some extent option, 62.8 percent have answered to high option and 35.0 percent have answered to very high option which the most frequency is related to high option.

Regarding to table (3-2), the calculated chi-square (17.768) is greater than the value of chi-square in the table (9.21), therefore, by a 99 percent confidence, it can be said that there is a meaningful difference between the observed frequencies and the expected frequencies. And this result indicates that using of information and communication technology has an impact to a high extent on increase in question-making skill of third grade secondary school students.

Third hypothesis of the research: using of information and communication and communication technology has an impact on increase in research spirit of third grade secondary school (high school) students (Table 4-1 and table 4-2).

Regarding to the data of table (4-1), 0 percent have answered to very low options, 0.3 percent have answered to low option, 1.9 percent have answered to To some extent option, 63.4 percent have answered to high option, and 34.4 percent have answered to very high option, which the most frequency is related to high option.

Regarding to table (4-2), the calculated chi-square (13.468) is larger than the value of chi-square in the table (11.34), therefore, by 99 percent confidence, it can be said that there is a meaningful difference between the observed frequencies and the expected frequencies. And this result indicates that using of information and communication technology has an impact to a high extent on increase in research spirit of third grade high school (secondary school) students.

Fourth hypothesis of the research: using of information and communication technology has an impact on increase in curricular scores of third grade secondary school students (Table 5-1 and table 5-2).

Regarding to the data of table (5-1), 0 percent have 3.1 percent have answered to To some extent option , 54.7 percent have answered to high option, and 42.2 percent have answered to very high option which the most (greatest) frequency is related to high option.

Regarding to table (5-2), the calculated chi-square (13.389) is larger than the value of chi-square in the table (9.21) ; therefore, by 99 percent confidence, it can be said that there is a meaningful difference between the observed frequencies and the expected frequencies. And this result indicates that using of information and communication technology has an impact to a high extent on increase in curricular scores of third grade high school students.

General hypothesis of the research: using of information and communication technology has an impact on educational improvement of third grade secondary school students (Table 6-1 and table 6-2).

Regarding to the data of table (6-1), 0 percent have answered to very low and low options , 1.6 percent have answered to To some extent option, 91.9 percent have answered to high option and 6.6 percent have answered to very high option which the most frequency is related to high option.

Regarding to table (6-2), the calculated chi-square (14.947) is larger than the value of chi-square in the table (9.21); therefore, by 99 percent confidence, it can be said that there is a meaningful difference between the observed frequencies and the expected frequencies. And this result indicates that using of information and communication technology has an impact to a high extent on the educational improvement of third grade high school students.

Gender: The impact of information and communication technology on the educational improvement of third grade secondary school students regarding to gender (Table 7-2).

Regarding to table (7-2), the obtained $u$ (1.170) in the level of 95 percent is smaller than critical value of the table (1.64); therefore, the difference is not statistically meaningful. And it can be concluded that there is no meaningful 
difference between using of information and communication technology and its impact on the educational improvement of girl and boy students in terms of gender. And its impact on girl and boy students is the same.

Type of institution: The impact of information and communication technology on educational improvement of third grade high school students regarding to school kind(Table 8-2).

According to table (8-2), the obtained $u(9.353)$ in the level of 95 percent is bigger than the critical value in the table (1.64) ; therefore, the difference is statistically meaningful. And it can be concluded that there is a meaningful difference between using of information and communication technology and its effect on the educational improvement of students studying in high school and technical school. And its impact on technical school students has been more than high school students.

Age: The effect of information and communication technology on the educational improvement of third grade secondary school students regarding to the age of students (Table 9-2).

Regarding to table (9-2), the calculated $\mathrm{X}_{2}(0.060)$ is smaller than the critical value of the table (3.84) by freedom degree of 1 in the level of 95 percent; therefore, the difference is not statistically meaningful. And it can be concluded that the effect of using of information and communication technology is the same on the educational improvement of third grade high school students in terms of age.

Educational field: The impact of information and communication technology on the educational improvement of third grade secondary school students regarding to educational field (Table 10-2).

According to table (10-2), the calculated $\mathrm{X}_{2}(1.480)$ is smaller than the critical value in the table (11.07) by a freedom degree of 5 in the level of 95 percent ; therefore, the difference is not statistically meaningful and it can be concluded that the impact of using of information and communication technology on the educational improvement of third grade secondary school students is the same in terms of educational field.

Average: The effect of information and communication technology on the educational improvement of third grade secondary school students regarding to the average (Table 11-2).

Regarding to table (11-2), the calculated $\mathrm{X}_{2}(6.822)$ is smaller than the critical value in the table (7.81) by a freedom degree of 3 in the level of 95 percent; therefore, the difference is not statistically meaningful. And it can be concluded that the impact of using of information and communication technology on the educational improvement of third grade secondary school students is the same in terms of average.

\section{Discussion and Conclusion}

Results of this research are as follows:

First hypothesis of the research: using of information and communication technology has an impact on increase in educational motivation of third grade secondary school students.

Regarding to research results, it was determined that 94.7 percent of respondents have emphasized on first hypothesis of the research in very high and high extent, for 5.3 percent, no answer was presented at middle and low and very low extents. In this same respect, the respondents have evaluated using of information and communication technology on increase in educational motivation to a high extent as effective.

According to the results ( $\mathrm{p}=0.000<0.01, \mathrm{df}=2, \mathrm{X}_{2}=12.171$ ), regarding to that the calculated chi-square (12.171) is larger than the value of chi-square in the table (9.21), it is concluded that by 99 percent confidence, there is a meaningful difference between the observed frequencies and the expected frequencies. And this result indicates that using of information and communication technology has an impact to a high extent on increase in educational motivation of third grade secondary school students.

This result is consistent with research findings of Islami (1387), Sandholtez \& Dwyer (1994), Pelegram \& lav (2003).

Second hypothesis of the research: using of information and communication technology has an impact on increase in question-making skill of third grade secondary school students.

Regarding to research results, it was determined that 97.8 percent of respondents have emphasized on second hypothesis of the research in very high and high extents, for 2.2 percent, no answer was presented in middle and low and very low extents. In this same respect, the respondents have evaluated using of information and communication technology to a high extent on increase in question-making skill as effective.

According to the results ( $\mathrm{p}=0.000<0.01, \mathrm{df}=2, \mathrm{x}_{2}=17.768$ ) regarding to that the calculated chi-square (17.768) is larger than the value of chi-square in the table $(9.21)$, it is concluded that by 99 percent confidence, there is a meaningful difference between the observed frequencies and the expected frequencies. And this result indicates that 
using of information and communication technology has an impact to a high extent on increase in question-making skill of third grade secondary school students.

This result is consistent with the research findings of Montazeri, Vakili and seyyed Ebrahimi (1385).

Third hypothesis of the research: using of information and communication technology has an impact on increase in research spirit of third grade secondary school students.

Regarding to research results, it was determined that 97.8 percent of respondents have emphasized on third hypothesis of the research in very high and high extents, 1.9 percent have pointed out to middle extent and 0.3 percent have pointed out to low and very low extents. In this same respect, the respondents have evaluated using of information and communication technology to a high extent on increase in research spirit as effective.

According to the results $\left(\mathrm{p}=0.000<0.01, \mathrm{df}=3, \mathrm{x}_{2}=13.468\right)$ regarding to that the calculated chi-square (13.468) is larger than the value of chi-square in the table (11.34), it is concluded that by 99 percent of significance, there is a meaningful difference between the observed frequencies and the expected frequencies. And this result indicates that using of information and communication technology has an impact to a high extent on increase in research spirit of third grade high school students.

This result is consistent with research findings of Taheri (1385), Imeni (1384), Haj Foroush and ourangi (1382), Rose cheli penoel and Abrahamson (2004), Sand Holtz.

Fourth hypothesis of the research: using of information and communication technology has an impact on increase in curricular scores of third grade secondary school students.

Regarding to research results, it was determined that 96.9 percent of respondents have emphasized on foueth hypothesis of the research to very high and high extents, for 3.1 percent, no answer was presented in middle and low and very low extents. In this same respect, the respondents have evaluated using of information and communication technology to a high extent on increase in curricular scores as effective.

According to the results $\left(\mathrm{p}=0.000<0.01, \mathrm{df}=2, \mathrm{x}_{2}=13.389\right)$ regarding to the that the calculated chi-square $(13.389)$ is larger than the value of chi-square in the table (9.21), it is concluded that by 99 percent of significance, there is a meaningful difference between the observed frequencies and the expected frequencies. And this result indicates that using of information and communication technology has an impact to a high extent on increase in curricular scores of third grade secondary school students.

This result is consistent with research findings of Najafi and Mohammadi (1385), Dalzil (2001).

General hypothesis of the research: using of information and communication technology has an impact on educational improvement of third grade secondary school students.

Regarding to research results, it was determined that 98.4 percent of respondents have emphasized on general hypothesis of the research which contains four previous hypotheses to very high and high extents , for 1.6 percent, no answer was presented in middle and low and very low extents. In this same respect, the respondents have evaluated using of information and communication technology to a high extent on the educational improvement as effective.

According to the result $\left(\mathrm{p}=0.000<0.01, \mathrm{df}=2, \mathrm{x}_{2}=14.947\right)$ regarding to that the calculated chi-square (14.947) is larger than the value of chi-square in the table (9.21), it is concluded that by 99 percent of significance, there is a meaningful difference between the observed frequencies and the expected frequencies. And this result indicates that using of information and communication technology has an impact to a high extent on educational improvement of third grade secondary school students.

This result is consistent with research findings of Montazeri and the colleagous (1385), Najafi and Mohammadi (1385), kelementz (2000).

Research findings indicate that using of information and communication technology has been effective to a high extent on increase in educational motivation, enhancement of question-making skill, enforcement of research spirit, increase in curricular scores and in total on educational improvement of third grade secondary school students.And this effectiveness has been the same among girl and boy students by different averages and ages and fields. But its technical school students and high school students.

\section{References}

Alinston, H. (2002). Corporate Planning, Forecasting and the Long Mave, Futures, No.34.

Baines, Anna. (1998), Using Information Technology to Facilitate Organizational Change, Work Study, MSB University Press, Vol.47, No.2. 
Delavar, A. (1379). Research method in psychology and training science, Tehran, Roshd publications, page 221. (In Persian).

Hardy, j.v. (1998). Teachers Attitudes toward and knowledge of computer technology. computer in the school journal, Vol. 14, No.3-4, pp.119-136

Hassanzadeh, Ramezan. (1383). Research methods in behavioral science, Tehran, publication of savalan. (In Persian).

Islami, Rajab Ali, (1387). study of development fields of ICT (Information and communication Technology) in general teaching schools in Mazandaran province, Mazandaran's Education organization, center of investigations. (In Persian).

Kurupparachchi, Palithe \& ross, Smith \& Purne, Mondar. (2002). IT Project implementation Strategies for Effective Change?, Review Lojestic Information Management, Vol.15, No.2.

Mehmet, Nuri. (2004). Use of educational Technology in English classes. The turkish online journal of Educational Technology, vol.3, Issue 2, Article 11. [Online] Avaliable: http:// tojet.net/ volumes/v3i2.pdf

Milleken, j. \& Bames, L.p. (2002). Teaching and Technology in higher Education: student perceptions reflections. Computer \& Education journal, vol.39, No.3, pp.223-235

Mohammadi, F. (1381).Recognition of information technology, Magazine of educational (teaching) technology, period $18 \mathrm{M}$, page 2. (In Persian).

Montazeri, Tayebeh. (1385). The effect of information technology revolutions on Education, set of papers (Articles) of the first IT (Information Technology) in Education, Yazd, Education organization. (In Persian).

Muata, kweku \& Bryson, Osei \& ko, Myung. (2003)."Exploring the relationship between information technology investment and firm performance using regression splints analysis", Department of information systems. [Online] Available: http://www.Elsevier.com / locate /dsw

McClea, Michael \& Yen, Divid.C. (2005), A Frame Work for the Utilization of Information Technology in higher Education Admission Department", International Journal of Educational Management, Vol.19. No.2, [Online] Available: http://www.emeraldinsight.com/research register

Norouzi, Ma'soumeh, and Rendi, Faramak and Mousa Madani , Fariborz, (1387). Ranking of application methods of information technology in schools, teaching-learning process, Quarterly of educational innovations. (In Persian).

Sandholtz j.h. Ringstaff C \& Dwyer D.C. (1994). Student Engagement Revisited: view from Technology-Rich classrooms. [Online] Available: http://www.apple.com/ education/ k12/leadership

Tileston, Donna Walked. (2004). What Every teacher should know about Media and Technology. unitedstates of America, corwin press, INC.

Yazdchi - Safoura. (1385), New role of teachers in Education regarding to information and communication technology development, set of papers (articles) of the first IT (information technology) conference in Education , Yazd, Education organization. (In Persian).

Zamani, Bibi Eshrat, and Babadi Akasheh, Zahra. (1385), The role of teachers in integration pattern of information and communication technology in curriculum (curricular program), set of papers (articles) of the first IT (Information Technology) conference in Education, Yazd, Education organization. (In Persian).

Zoghipour, Abbas, and Ghaffari, Samad. (1384) , Multi-media school, a step towards intelligent schools. Set of papers (articles) in the first IT (Information Technology) in Education, Yazd, Education organization. (In Persian).

Table 1-1. Frequency of statistical population according to gender separation

\begin{tabular}{|c|c|c|c|}
\hline thender grade & Girl & Boy & Total \\
\hline in secondary school & & 1170 & 1900 \\
\hline Population Frequency (fi) & 730 & $62 \%$ & $100 \%$ \\
\hline Percentage (pi) & $38 \%$ & $62 \%$ & \\
\hline
\end{tabular}


Table 1-2. Distribution of frequency percentage of statistical sample according to gender

\begin{tabular}{|c|c|c|c|}
\hline Tender third grade & Girl & Boy & Total \\
\hline in secondary school & & 197 & 320 \\
\hline Sample Frequency (fi) & 123 & $62 \%$ & $100 \%$ \\
\hline Percentage (pi) & $38 \%$ & & \\
\hline
\end{tabular}

Table 2-1. Distribution of frequency percentage of respondents to first hypo thesis of the research

\begin{tabular}{|c|c|c|c|c|c|}
\hline Very Low & low & To some extent & High & Very high & Total \\
\hline 0 & 0 & 17 & 226 & 77 & 320 \\
\hline 0 & 0 & 5.3 & 70.6 & 24.1 & 100.0 \\
\hline
\end{tabular}

Table 2-2. Results of chi-square test in relation to first hypothesis of the research

\begin{tabular}{|c|c|c|}
\hline Sig & X2 & Df \\
\hline 0.000 & 12.171 & 2 \\
\hline
\end{tabular}

Table 3-1. Distribution of frequency percentage of respondents to second hypothesis of the research

\begin{tabular}{|c|c|c|c|c|c|c|}
\hline Variable & Very Low & low & To some extent & High & Very high & Total \\
\hline Frequency & 0 & 0 & 7 & 201 & 112 & 320 \\
\hline Percentage & 0 & 0 & 2.2 & 62.8 & 35.0 & 100.0 \\
\hline
\end{tabular}

Table 3-2. Results of chi-square test in relation to second hypothesis of the research

\begin{tabular}{|c|c|c|}
\hline Sig & X2 & Df \\
\hline 0.000 & 17.768 & 2 \\
\hline
\end{tabular}

Table 4-1. Distribution of frequency percentage of respondents to third hypothesis of the research

\begin{tabular}{|c|c|c|c|c|c|c|}
\hline Variable & Very Low & low & To some extent & High & Very high & Total \\
\hline Frequency & 0 & 1 & 6 & 203 & 110 & 320 \\
\hline Percentage & 0 & 0.3 & 1.9 & 63.4 & 34.4 & 100.0 \\
\hline
\end{tabular}

Table 4-2. Results of chi-square test in relation to third hypothesis of the research

\begin{tabular}{|c|c|c|}
\hline Sig & X2 & Df \\
\hline 0.000 & 13.468 & 3 \\
\hline
\end{tabular}


Table 5-1. Distribution of frequency percentage of respondents to fourth hypothesis of the research

\begin{tabular}{|c|c|c|c|c|c|c|}
\hline Variable & Very Low & low & To some extent & High & Very high & Total \\
\hline Frequency & 0 & 0 & 10 & 175 & 135 & 320 \\
\hline Percentage & 0 & 0 & 3.1 & 54.7 & 42.2 & 100.0 \\
\hline
\end{tabular}

Table 5-2. Results of chi-square test in relation to fourth hypothesis of the research

\begin{tabular}{|c|c|c|}
\hline Sig & X2 & Df \\
\hline 0.000 & 13.389 & 2 \\
\hline
\end{tabular}

Table 6-1. Distribution of frequency percentage of respondents to general hypothesis of the research

\begin{tabular}{|c|c|c|c|c|c|c|}
\hline Variable & Very Low & low & To some extent & High & Very high & Total \\
\hline Frequency & 0 & 0 & 5 & 294 & 21 & 320 \\
\hline Percentage & 0 & 0 & 1.6 & 91.9 & 6.5 & 100.0 \\
\hline
\end{tabular}

Table 6-2. Results of chi-square test in relation to general hypothesis of the research

\begin{tabular}{|c|c|c|}
\hline Sig & X2 & Df \\
\hline 0.000 & 14.947 & 2 \\
\hline
\end{tabular}

Table 7-2. Results of $U$ mann-whitny test in relation to gender

\begin{tabular}{|c|c|c|c|c|c|c|}
\hline \multicolumn{2}{|c|}{ Property } & N & M & Umann-whitny & Z & Sig \\
\hline \multirow{3}{*}{ Gender } & Girl & 123 & 163.89 & & & \\
\cline { 2 - 7 } & Boy & 197 & 158.38 & 1.170 & 1.116 & 0.265 \\
\hline
\end{tabular}

Table 8-2. Results of umann-whitny test in relation to school kind

\begin{tabular}{|c|c|c|c|c|c|c|}
\hline \multicolumn{2}{|c|}{ Property } & N & M & Umann-whitny & Z & Sig \\
\hline \multirow{2}{*}{$\begin{array}{c}\text { Kind of } \\
\text { school }\end{array}$} & High school & 243 & 160.49 & & & \\
\cline { 2 - 6 } & $\begin{array}{c}\text { Technical } \\
\text { school }\end{array}$ & 77 & 160.53 & 9.353 & 0.08 & 0.390 \\
\hline
\end{tabular}


Table 9-2. Results of kruskal-wallis test regarding to the age of students

\begin{tabular}{|c|c|c|c|c|c|c|}
\hline \multicolumn{2}{|c|}{ Property } & N & M & $X_{2}$ & Df & Sig \\
\hline \multirow{3}{*}{ Age } & 15 -year old & 0 & 0 & & & \\
\cline { 2 - 4 } & 16 -year old & 30 & 162.33 & \multirow{2}{*}{0.060} & 1 & 0.806 \\
\cline { 2 - 4 } & 17 -year old & 290 & 160.31 & & & \\
\hline
\end{tabular}

Table 10-2. Results of kruskal-wallis test regarding to educational field

\begin{tabular}{|c|c|c|c|c|c|c|}
\hline \multicolumn{2}{|c|}{ Property } & $\mathrm{N}$ & M & $\mathrm{X}_{2}$ & Df & Sig \\
\hline \multirow{6}{*}{ Field } & Mathematics \& physics & 83 & 163.36 & \multirow{6}{*}{1.480} & \multirow{6}{*}{5} & \multirow{6}{*}{0.915} \\
\hline & Empirical science & 80 & 161.00 & & & \\
\hline & Humanities & 80 & 157.00 & & & \\
\hline & Computer & 40 & 157.00 & & & \\
\hline & Electronics & 20 & 165.00 & & & \\
\hline & Mapping & 17 & 163.59 & & & \\
\hline
\end{tabular}

Table 11-2. Results of kruskal-wallis test regarding to the average

\begin{tabular}{|c|c|c|c|c|c|c|}
\hline \multicolumn{2}{|c|}{ Property } & $\mathrm{N}$ & M & $\mathrm{X}_{2}$ & Df & Sig \\
\hline \multirow{4}{*}{ Average } & $12-14$ & 4 & 133.00 & \multirow{4}{*}{6.822} & \multirow{4}{*}{3} & \multirow{4}{*}{0.078} \\
\hline & $14-16$ & 65 & 453.31 & & & \\
\hline & $16-18$ & 117 & 167.53 & & & \\
\hline & $18-20$ & 136 & 158.67 & & & \\
\hline
\end{tabular}

